Florida International University FIU Digital Commons

FCE LTER Journal Articles

FCE LTER

2006

\title{
Variation in soil phosphorus, sulfur, and iron pools among south Florida wetlands
}

\author{
Randolph M. Chambers \\ Keck Environmental Lab, College of William and Mary \\ Kristin A. Pederson \\ Keck Environmental Lab, College of William and Mary
}

Follow this and additional works at: https://digitalcommons.fiu.edu/fce_lter_journal_articles

\section{Recommended Citation}

Chambers, R.M., K.A. Pederson. 2006. Variation in soil phosphorus, sulfur, and iron pools among south Florida wetlands. Hydrobiologia 569(1): 63-70.

This material is based upon work supported by the National Science Foundation through the Florida Coastal Everglades Long-Term Ecological Research program under Cooperative Agreements \#DBI-0620409 and \#DEB-9910514. Any opinions, findings, conclusions, or recommendations expressed in the material are those of the author(s) and do not necessarily reflect the views of the National Science Foundation. This work is brought to you for free and open access by the FCE LTER at FIU Digital Commons. It has been accepted for inclusion in FCE LTER Journal Articles by an authorized administrator of FIU Digital Commons. For more information, please contact dcc@fiu.edu, jkrefft@fiu.edu. 


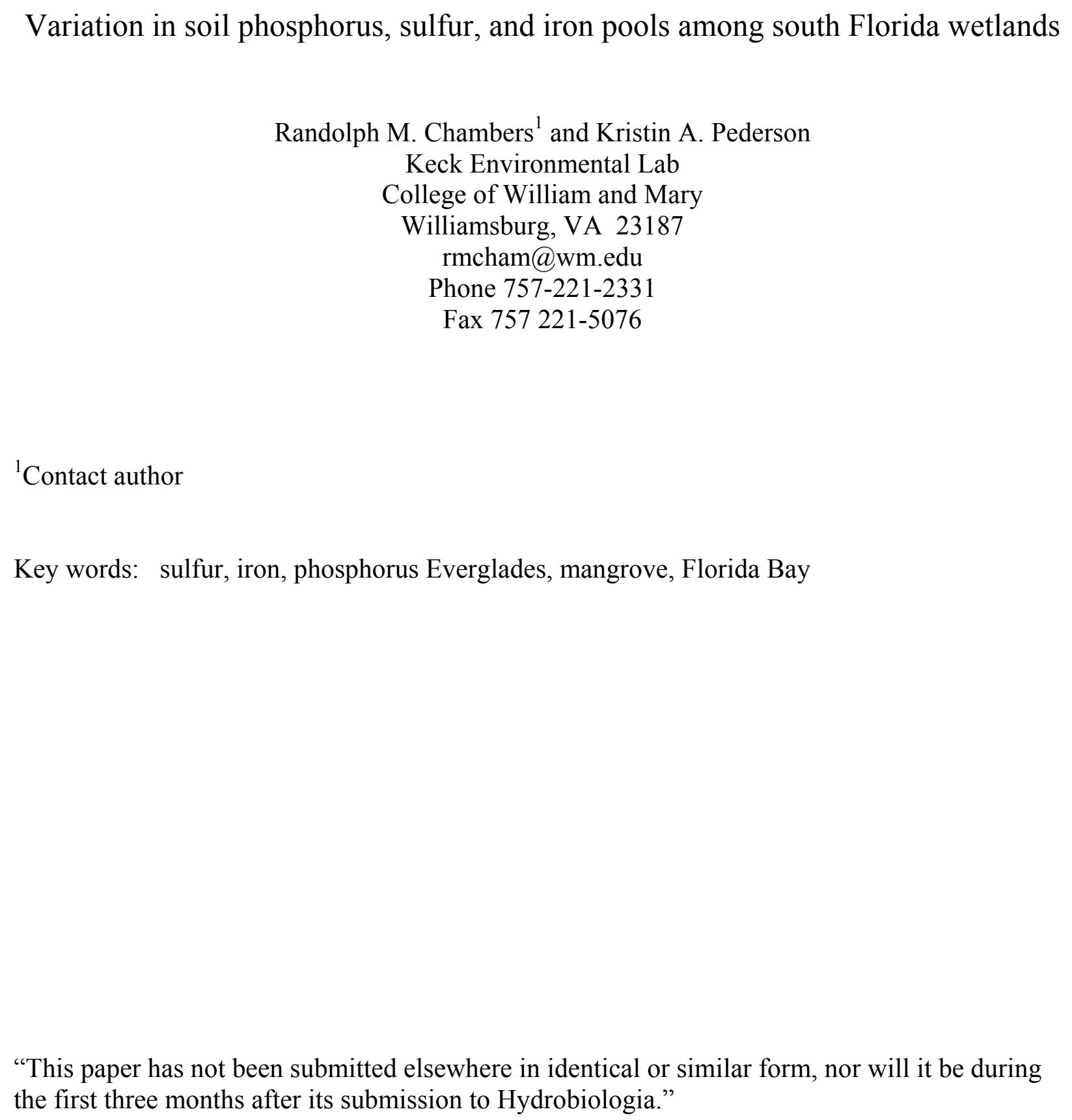

\section{Variation in soil phosphorus, sulfur, and iron pools among south Florida wetlands}

\author{
Randolph M. Chambers ${ }^{1}$ and Kristin A. Pederson
} Keck Environmental Lab College of William and Mary

Williamsburg, VA 23187

rmcham@wm.edu

Phone 757-221-2331

Fax 757 221-5076

${ }^{1}$ Contact author

Key words: sulfur, iron, phosphorus Everglades, mangrove, Florida Bay

"This paper has not been submitted elsewhere in identical or similar form, nor will it be during the first three months after its submission to Hydrobiologia." 
To determine relationships between soil nutrient status and known gradients in primary production, we collected and analyzed soils from 17 LTER sampling sites along two transects through south Florida wetland ecosystems. Through upstream freshwater marsh, a middle reach including the oligohaline marsh/mangrove ecotone, and downstream estuarine habitats, we observed systematic variation in soil bulk density, organic content, and pools of phosphorus (P), inorganic sulfur, and extractable iron. Consistent with observed differences in wetland productivity known to be limited by $\mathrm{P}$ availability, total $\mathrm{P}$ averaged $\sim 200 \mu \mathrm{gdw}^{-1}$ in soils from the eastern Taylor Slough/Panhandle and was on average three times higher in soils from the western Shark River Slough. Along both transects, the largest pool of phosphorus was the inorganic, carbonate-bound fraction, comprising $35-44 \%$ of total P. Greater than $90 \%$ of the total inorganic sulfur pool in these south Florida wetland soils was extracted as pyrite.

Freshwater marsh sites typically were lower in pyrite sulfur $\left(0.2-0.8 \mathrm{mg} \mathrm{gdw}^{-1}\right)$ relative to marsh/mangrove ecotone and downstream estuary sites $\left(0.5-2.9 \mathrm{mg} \mathrm{gdw}^{-1}\right)$. Extractable iron in freshwater marsh soils was significantly higher from the Taylor Slough/Panhandle transect (3.2 $\left.\mathrm{mg} \mathrm{gdw}^{-1}\right)$ relative to the western Shark River Slough transect $\left(1.1 \mathrm{mg} \mathrm{gdw}^{-1}\right)$, suggesting spatial variation in sources and/or depositional environments for iron. Further, these soil characteristics represent the collective, integrated signal of ecosystem structure, so any long-term changes in factors like water flow or water quality may be reflected in changes in bulk soil properties. Since the objective of current Everglades restoration initiatives is the enhancement and re-distribution of freshwater flows through the south Florida landscape, the antecedent soil conditions reported here provide a baseline against which future, post-restoration measurements can be compared. 
71 The south Florida landscape is dominated by vegetated freshwater, brackish mangrove and

72 downstream estuarine habitats. These different wetlands exhibit variable primary production both within and between habitat types. For example, Fourqurean et al. (1992a,b) have documented the pronounced gradient in seagrass production throughout the Florida Bay estuary as a function of phosphorus availability. Nutrient availability also contributes to the greater mangrove biomass along the southwest coast of the Everglades (Chen \& Twilley 1999) relative to mangrove biomass on the southeast coast (Coronado-Molina et al. 2004). Similarly, across the freshwater Everglades, Childers et al. (2003) have documented differences in vegetation and biomass related to soil phosphorus concentrations.

Given the general characteristics of phosphorus limitation in south Florida wetlands (Koch \& Reddy 1992; Noe et al. 2001, 2002) coupled with a 100-year old history of changes in water flow largely driven by installation and operation of water control structures (Light \& Dineen 1994; Chimney and Goforth 2001), any factors that influence the supply of phosphorus or alter the flows of water through these oligotrophic wetlands could impart dramatic changes on ecosystem structure and function (Fourqurean et al. 2003; Davis et al. 2004). To this end, the Florida Coastal Everglades Long-Term Ecological Research (LTER) program was established to examine variability in regional climate, freshwater inputs, disturbance, and perturbations affecting the coastal Everglades ecosystem. As part of the LTER program, we have initiated synoptic sampling of soils across the south Florida landscape with identical analytical methods to 
capture in a snapshot some of the differences and similarities in soil characteristics among wetland types.

Soil properties can be viewed as the integrated outcome of processes occurring over extended time scales, much in the same way that climate is a description of aggregate weather conditions for a region. In this study we present the aggregate soil properties along two transects, with a focus on forms of phosphorus, sulfur and iron. Phosphorus is a limiting nutrient in these oligotrophic wetlands and has been used to characterize ecological community types in other Florida habitats (Schwandes et al. 2001). Reduced inorganic sulfur is the by-product of the principle anaerobic respiratory process in marine and estuarine soils (sulfate reduction); soil sulfide exerts some control on mercury speciation (Benoit et al. 1999) and can also be used to track sulfate sources (Bates et al. 2002). In turn, both the phosphorus and sulfur cycles in soils are influenced by the availability of reactive iron in carbonate soils (Sherman et al. 1998). Our objective was to quantify the pools of sulfur, iron and phosphorus in different wetland soils and establish a baseline for tracking long-term changes in the coastal Everglades ecosystem.

\section{Methods}

Study Site

The south Florida landscape is dominated by sub-tropical wetland environments where hydrology — in terms of water volume, source, and residence time - plays a major factor in ecosystem structure (e.g., Ross et al. 2003). As part of the Florida Coastal Everglades LTER, two transects along separate freshwater drainage networks in the Everglades have been established (Figure 1). In the western Everglades, six sampling sites are located in the Shark 
114 River Slough (SRS) basin, extending from freshwater marsh (SRS sites 1 and 2), through the

115 oligohaline marsh/mangrove forest ecotone (SRS sites 3 and 4), and out through coastal estuarine

116 mangroves (SRS sites 5 and 6). Eight sampling sites are located in the eastern Taylor

117 Slough/Panhandle basin, extending from freshwater marsh (TS/Ph sites 1, 2, and 4), through a

118 region including the oligohaline marsh/mangrove forest ecotone (TS/Ph sites 3, 5, 6, 7, and 8),

119 and out to the seagrass-dominated Florida Bay estuary (TS/Ph sites 9-11).

121 Relative to the $\mathrm{TS} / \mathrm{Ph}$ drainage, $\mathrm{SRS}$ is characterized during the wet season by larger inflows of

122 freshwater from canal discharge at SRS 1 and greater tidal exchange of coastal ocean water at SRS 6. Additionally, soils in the SRS basin tend to be peaty, whereas soils in the $\mathrm{TS} / \mathrm{Ph}$ basin

124 have less peat and more marl deposits (Childers et al. 2003). Florida Bay sediments are almost exclusively comprised of marine carbonates.

\section{Soil Collection and Analysis}

128 Soils for determination of organic content were collected in August 2002; soils for all other analyses were collected during August 2003. From each of the 17 sampling sites, three 60-ml syringe cores were pushed into the soil surface to a depth a $10 \mathrm{~cm}$. The syringe barrels were

131 capped with butyl rubber stoppers and stored on ice for transport to the laboratory, then cores

132 were refrigerated prior to analysis. Cores were extruded, and subsamples from each core were

133 obtained at depths from $0-2.5 \mathrm{~cm}, 2.5-5.0 \mathrm{~cm}$, and $5.0-10 \mathrm{~cm}$.

135 Soils from all 17 sampling sites were treated identically. Soil samples for bulk density, \% organic matter, total phosphorus and extractable iron analyses were placed in tared vials, dried at 
$13780^{\circ} \mathrm{C}$ and weighed to determine bulk density, then ashed at $450^{\circ} \mathrm{C}$ for four hours to determine

138 weight loss on ignition. The ashed soils were then resuspended in $1 \mathrm{~N} \mathrm{HCl}$ to hydrolyze

139 phosphates, and colorimetric analyses for total phosphorus using the ascorbate method and

140 extractable iron $\left(\mathrm{Fe}_{\mathrm{HCl}}\right)$ using the ferrozine method (Stookey 1970) were completed.

141

142

143

144

145

146

147

148

149

150

151

152

153

154

155

156

157

158

159

A four-step sequential extraction scheme based on a method used by Jensen et al. (1998) and Koch et al. (2001) was completed to determine selected inorganic and organic pools of phosphorus in carbonate sediment. First, extraction with $1 \mathrm{~N}$ magnesium chloride released loosely sorbed inorganic phosphate $\left(\mathrm{P}_{\mathrm{MgCl}}\right)$. Next, extraction with a buffered dithionite solution released inorganic phosphate considered sorbed to metal oxides (principally iron and manganese compounds $)\left(\mathrm{P}_{\mathrm{BD}}\right)$. Third, extraction with $1 \mathrm{~N} \mathrm{HCl}$ dissolved the carbonate minerals in the soil and released inorganic phosphate sorbed to or in mineral phase with calcium carbonate $\left(\mathrm{P}_{\mathrm{HCl}}\right)$.

Finally, subsequent ashing and $1 \mathrm{~N} \mathrm{HCl}$ acid extraction was used to release recalcitrant phosphate, operationally defined as the residual organic phosphorus fraction $\left(\mathrm{P}_{\mathrm{Org}}\right)$. Less resistant organic phosphates associated with the first three extraction steps were not analyzed, but have been shown to account for $10-30 \%$ of the total sediment phosphorus in Florida Bay seagrass beds (Koch et al. 2001).

Soil samples for mineral sulfide extraction were first suspended in $1 \mathrm{~N}$ zinc acetate to precipitate any free sulfide in solution. Then, the soils were subjected to a two-step sulfur extraction sequence following the method used by Chambers et al. (1994). Acid-volatile sulfide (AVS) was extracted using a $1 \mathrm{~N} \mathrm{HCl}$ solution, then sequestered in an $\mathrm{NaOH}$ trap. Chromium-reducible sulfide (CRS) was extracted using a boiling solution of concentrated $\mathrm{HCl}$ and reduced chromium, 
160 then sequestered in an $\mathrm{NaOH}$ trap. The trapped AVS and CRS fractions were fixed using Cline's

161 reagent and analyzed colorimetrically (Cline 1969). The CRS fraction was assumed to be pyrite

$162\left(\mathrm{FeS}_{2}\right)$.

163

164 Total phosphorus concentrations were calculated both by soil weight and by volume to allow for 165 comparison with other published values. All other nutrient concentrations were calculated per 166 weight of soil and compared among transect locations (i.e., freshwater marsh, oligohaline $167 \mathrm{marsh} /$ mangrove forest, downstream estuary). One way ANOVAs were used to compare means

168

169

170

171

172

173

174

175

176

177

178

179

180

181 among transect locations, and LSD post hoc comparisons were completed using SPSS Version 10.0 (SPSS 1999). Percent organic values were log-transformed to normalize the data prior to statistical analysis.

\section{Results and Discussion}

Total P concentration typically was higher along the Shark River Slough transect relative to the Taylor Slough/Panhandle transect (Table 1). Expressed by soil weight, total $\mathrm{P}$ was fairly constant from SRS 2 through SRS 6; per soil volume, however, total P increased down the transect. Plant roots respond to changes in nutrient density, and the pattern of downstream soil P enrichment is consistent with an observed gradient in mangrove productivity along the SRS transect (Chen and Twilley 1999). Along the TS/Ph transect, however, total P concentration decreased from the most northern freshwater marsh sites before rising at $\mathrm{TS} / \mathrm{Ph} 7$ and 8 to values similar to those measured at SRS 4-6. The profound difference in mangrove production between SRS and TS/Ph transects (Coronado-Molina et al. 2004) despite similar total P 
concentration in the soil demonstrates that other factors in addition to soil P content influence wetland productivity.

We expected to see a gradient of decreasing total $\mathrm{P}$ in sediment from west-to-east across Florida Bay, concomitant with prior research demonstrating a bay-wide gradient in $\mathrm{P}$ availability and seagrass production (Fourqurean et al. 1992a,b). We found, however, that sediment $\mathrm{P}$ was unusually high in the eastern portion of Florida Bay (TS/Ph 9; Table 1). This site is located adjacent to Duck Key where a heron rookery was recently established, so our measured high $\mathrm{P}$ value at $\mathrm{TS} / \mathrm{Ph} 9$ may be a result of localized $\mathrm{P}$ enrichment from bird guano.

All soils in the current study were calcareous, but soil bulk density was significantly lower in freshwater marsh environments and along the SRS transect (Table 2). The most dense soils were located in Florida Bay. Concomitant with high bulk density in Florida Bay seagrass meadows was low percent organic matter, averaging about 7\%. In contrast, the emergent freshwater marshes and mangrove forest soils had much higher organic content, and organic content was significantly higher along the Shark River Slough transect. The implication from these data is that marly soils are more consolidated or compacted along the Taylor Slough/Panhandle transect, with higher water content in soils along the SRS transect.

As found in a prior study of sulfur in Everglades soils (Bates et al. 1998), the acid-volatile component of the extracted soil sulfur pool was always less than $10 \%$ (Table 2 ). The concentration of AVS, which includes free sulfide ( $\mathrm{HS}^{-}$) plus iron monosulfide (FeS), was significantly higher in the marsh/mangrove ecotone of both transects. Most inorganic sulfide, however, was extracted in the CRS fraction. As expected, the CRS concentration was highest in 
205 the wetland habitats influenced by saltwater, the largest source of sulfate for bacterial sulfate

206 reduction to sulfide and subsequent pyrite formation. Between marsh, ecotone, and estuarine

207 wetland types, CRS was significantly higher along the SRS transect, relative to the TS/Ph

208 transect.

210 Extractable iron concentration was typically very low throughout all habitats sampled, but higher 211 along the eastern $\mathrm{TS} / \mathrm{Ph}$ transect (Table 2). Still, the average concentration of $\mathrm{Fe}_{\mathrm{HCl}}$ from the 212 TS/Ph mangrove sites $\left(\sim 1.7 \mathrm{mg} \mathrm{gdw}^{-1}\right)$ was roughly six times lower than the total soil iron 213 measured in a prior study sampling the mangrove fringe in the Taylor Slough drainage (Koch et

214 al. 2001). Because pyrite authigenesis relies on the availability of reactive iron and sulfide, 215 either species could limit its formation. Further, sulfate reduction only occurs in anaerobic soils 216 where labile organic matter is available for microbial decomposition. Relative to soils in 217 mangrove and seagrass habitats, freshwater marsh soils are exposed to lower concentrations of 218 sulfate, they experience oxidation during seasonal drawdowns of water, and microbial 219 decomposition of organic matter can be limited by phosphorus availability (Amador and Jones 220 1993). Together, these features are consistent with less net mineral sulfide formation in 221 freshwater marsh environments and more generally along the TS/Ph transect. Though different in magnitude between transects, the patterns in pool sizes of total phosphorus 224 and total inorganic sulfur were fairly similar among transect locations (Figure 2). Brown \& 225 Cohen (1995) completed a sediment survey along a transect line running from Florida Bay, 226 through the mangrove fringe and into freshwater marsh habitat near Whitewater Bay. They 227 found a pattern in mineral sulfide accumulation that was highest in the mangrove fringe, lowest 
228 in the freshwater marsh, and intermediate in Florida Bay. Not only is the coastal ocean the 229 primary source of sulfate for eventual sulfide production and mineral sulfide formation; the 230 coastal ocean is also the source of much of the phosphorus enrichment observed in both Florida 231 Bay and saltwater mangrove habitats along both SRS and TS/Ph transects (Figure 2).

232 Fourqurean et al. (1992a,b) have demonstrated the longitudinal decrease in phosphorus 233 deposition in Florida Bay from west to east, effectively showing the primary source of $\mathrm{P}$ in the 234 bay is the Gulf of Mexico. Similarly, Chen and Twilley (1999) have documented that soil 235 phosphorus concentration in mangrove forests along the SRS transect decreases with distance upstream from the Gulf of Mexico. The pattern of $\mathrm{P}$ enrichment in the coastal zone is smaller along the Taylor Slough transect (Figure 2), but consistent with the documented decrease in total 238 phosphorus concentration in the eastern portion of Florida Bay (Boyer et al. 1997).

Our sequential extraction scheme identified the three principal inorganic soil phosphorus pools and what has been measured as the major organic phosphorus pool in organic carbonate sediments (Koch et al. 2001) (Table 3). The easily desorbed $\mathrm{P}_{\mathrm{MgCl}}$ pool was usually less than

$24310 \%$ of total extracted $\mathrm{P}$. The size of the $\mathrm{P}_{\mathrm{BD}}$ pool was approximately $25 \%$ of the total extracted 244 P, whereas Koch et al. (2001) found the $\mathrm{P}_{\mathrm{BD}}$ fraction typically was below detection in organic 245 carbonate soils. We have not resolved this difference but note that the similar, large size of the $246 \mathrm{P}_{\mathrm{BD}}$ pool across wetland types (Table 2) suggests we may have extracted other forms of $\mathrm{P}$ not 247 associated with metal oxides in this fraction. Collectively, the average of the summed P 248 fractions $\left(124 \mu \mathrm{g} \mathrm{gdw}^{-1} \pm 21\right.$ s.e. $)$ was not significantly different from the independent 249 measurement of total $\mathrm{P}$ in Table $1\left(129 \mu \mathrm{gdw}^{-1} \pm 33\right.$ s.e. $)($ paired t-test, $\mathrm{t}=0.437, \mathrm{p}=0.33)$, but 
we do not know whether any of the unmeasured organic fractions could have been detected spectrophotometrically without prior ashing of the extract.

$\mathrm{P}_{\mathrm{HCl}}$, the fraction considered bound to calcium carbonate minerals, made up between 34 and $44 \%$ of extracted $\mathrm{P}$ and was consistently the largest $\mathrm{P}$ fraction.(Table 3). The carbonate-bound $\mathrm{P}$ pool has great potential to vary among these wetland soils because the bulk density (and thus mineral density) among sites varies by a factor of 4 (Table 2). Together, bulk density and the size of the $\mathrm{P}_{\mathrm{HCl}}$ pool highlight the potential importance of carbonate-bound $\mathrm{P}$ to observed variability in productivity within freshwater marsh (Childers et al. 2003), mangrove (Chen and Twilley 1999) and estuarine seagrass (Fourqurean et al. 1992b) habitats in the south Florida landscape. Although the sources and amounts of deposited P can be different for different habitats (e.g., P sources from coastal ocean water, terrestrial runoff and groundwater, atmospheric deposition), much of the variation in soil storage of phosphorus is due to variation in the carbonate-bound $\mathrm{P}$ pool (Zhang et al. 2004), even though short-term P storage occurs in organic plant and periphyton pools (McCormick et al. 1996; Dodds 2003; Noe et al. 2003).

\section{Bioavailability of carbonate-bound $\mathrm{P}$ has not been demonstrated clearly but is suggested from} other studies. In subtropical environments where primary production is enhanced by $\mathrm{P}$ enrichment or fertilization (DeBusk et al. 2001; Ferdie \& Fourqurean 2004), soil accumulation of P could be a direct consequence of organic matter deposition and decomposition (Romero et al. 2005), leading to $\mathrm{P}$ storage in carbonates. The stored $\mathrm{P}$ could then contribute to enhanced production when soil processes such as sulfate reduction solubilize the calcium carbonate matrix (Ku et al. 1999) and release inorganic phosphorus for plant uptake. Since sulfate reduction is 
greatest in marine and estuarine wetland soils (but see Bates et al. 2002), a dynamic system of inorganic $\mathrm{P}$ storage and $\mathrm{P}$ release ultimately may control whether carbonate-bound phosphorus operates as a sink or a source in freshwater, brackish, and marine wetland soils. A number of possible feedbacks involving carbonate saturation, wetland hydroperiod, organic matter and sulfate supply would influence soil phosphorus dynamics in the south Florida wetland environments.

\section{The Florida Coastal Everglades LTER program is designed to study the structure and function of} subtropical aquatic ecosystems and determine how different forces contribute to long-term stasis or ecosystem change. As part of that effort we measured soil characteristics across south Florida habitats distinguished by hydrology and wetland type. Along transects through upstream freshwater marsh, a middle reach including the oligohaline marsh/mangrove ecotone, and downstream estuarine habitats we observed systematic variation in soil bulk density, organic content, extractable iron, and pools of phosphorus and inorganic sulfur. Many of these soil characteristics represent a collective, integrated signal of ecosystem structure, so any long-term changes in factors like water flow or water quality may be reflected in changes in bulk soil properties. Since the objective of current Everglades restoration initiatives is the enhancement and re-distribution of freshwater flows through the south Florida landscape (Chimney and Goforth 2001; Perry 2004), the antecedent soil conditions reported here are part of a five-year time series to provide a baseline against which future, post-restoration measurements can be compared. 
295 Thanks to Timothy Russell and the FCE-LTER crew for field support, and to three anonymous 296 reviewers for their comments on earlier drafts of the manuscript. This material is based upon 297 work supported by the National Science Foundation under Grant No. 9910514.

298

299

300

301

302

303

304

305

306

307

308

309

310

311

312

313

314

315

316

\section{Literature Cited}

Amador, J.A. \& R.D. Jones. 1993. Nutrient limitations on microbial respiration in peat soils with different phosphorus content. Soil Biology \& Biogeochemistry 25: 793-801.

Bates, A.L., W.H. Orem, J.W. Harvey \& E.C. Spiker. 2002. Tracing sources of sulfur in the Florida Everglades. Journal of Environmental Quality 31: 287-299.

Bates, A.L., E.C. Spiker \& C.W. Holmes. 1998. Speciation and isotopic composition of sedimentary sulfur in the Everglades, Florida, USA. Chemical Geology 146: 155-170.

Benoit, J.M., C.C. Gilmour, R.P. Mason \& A. Heyes. 1999. Sulfide controls on mercury speciation and bioavailability to methylating bacteria in sediment pore waters. Environmental Science and Technology 33: 951-957.

Boyer, J.N., J.W. Fourqurean \& R.D. Jones. 1997. Spatial characterization of water quality in Florida Bay and Whitewater Bay by principal component and cluster analyses: Zones of similar influence (ZSI). Estuaries 20: 743-758. 
317 Brown, K.E. \& A.D. Cohen. 1995. Stratigraphic and micropetrographic occurrences of pyrite in 318 sediments at the confluence of carbonate and peat-forming depositional systems, southern 319 Florida, USA. Organic Geochemistry 22: 105-126.

320

321 322 323

Chambers, R.M., J.T. Hollibaugh \& S.M. Vink. 1994. Sulfate reduction and sediment metabolism in Tomales Bay, California. Biogeochemistry 25: 1-18.

Chen, R. \& R.R. Twilley. 1999. Patterns of mangrove forest structure associated with soil nutrient dynamics along the Shark River estuary. Estuaries 22: 1027-1042.

Childers, D.L., R.F. Doren, R. Jones, G.B. Noe, M. Rugge \& L.J. Scinto. 2003. Decadal change in vegetation and soil phosphorus pattern across the Everglades landscape. Journal of Environmental Quality 32: 344-362.

Chimney, M.J. \& G. Goforth. 2001. Environmental impacts to the Everglades ecosystem: a historical perspective and restoration strategies. Water Science and Technology 44: 93-100.

Cline, J.D. 1969. Spectrophotometric determination of hydrogen sulfide in natural waters. Limnology \& Oceanography 14: 454-459.

Coronado-Molina, J.W. Day, E. Reyes \& B.C. Perez. 2004. Standing crop and aboveground biomass partitioning of a dwarf mangrove forest in Taylor River Slough, Florida. Wetlands Ecology and Management 12: 157-164. 
341 Davis, S.E., J.E. Cable, D.L. Childers, C. Coronado-Molina, J.W. Day, C.D. Hittle, C.J. Madden,

342 E. Reyes, D. Rudnick \& F. Sklar. 2004. Importance of storm events in controlling ecosystem

343 structure and function in a Florida gulf coast estuary. Journal of Coastal Research 20: 1198-

3441208.

345

346 DeBusk, W.F., S. Newman \& K.R. Reddy. 2001. Spatio-temporal patterns of soil phosphorus

347 enrichment in Everglades Water Conservation Area 2A. Journal of Environmental Quality 30:

$348 \quad 1438-1446$.

349

350 Dodds, W.K. 2003. The role of periphyton in phosphorus retention in shallow freshwater

351 aquatic systems. Journal of Phycology 39: 840-849.

352

353 Ferdie, M. \& J.W. Fourqurean. 2004. Responses of seagrass communities to fertilization along

354 a gradient of relative availability of nitrogen and phosphorus in a carbonate environment.

355 Limnology and Oceanography 49: 2082-2094.

356

357 Fourqurean, J.W., J.N. Boyer, M.J. Durako, L.N. Hefty \& B.J. Peterson. 2003. Forecasting

358 responses of seagrass distributions to changing water quality using monitoring data. Ecological

359 Applications 13: 474-489.

360

361 Fourqurean, J.W., J.C. Zieman \& G.V.N. Powell. 1992a. Relationships between porewater

362 nutrients and seagrasses in a subtropical carbonate environment. Marine Biology 114: 57-65. 
364 Fourqurean, J.W., J.C. Zieman \& G.V.N. Powell. 1992b. Phosphorus limitation of primary

365 production in Florida Bay: Evidence from the C:N:P ratios of the dominant seagrass Thalassia

366 testudinum. Limnology and Oceanography 37: 162-171.

367

368 Jensen, H.S., K.J. McGlathery, R. Marine \& R.W. Howarth. 1998. Forms and availability of 369 sediment phosphorus in carbonate sand of Bermuda seagrass beds. Limnology and

370 Oceanography 43: 799-810.

371

372 Koch, M.S., R.E. Benz \& D.T. Rudnick. 2001. Solid-phase phosphorus pools in highly organic 373 carbonate sediments of northeastern Florida Bay. Estuarine, Coastal and Shelf Science 52: 279374291.

376 Koch, M.S. \& K.R. Reddy. 1992. Distribution of soil and plant nutrients along a trophic 377 gradient in the Florida Everglades. Soil Science Society American Journal 56: 1492-1499. 378

379 Ku, T.C.W., L.M. Walter, M.L. Coleman, R.E. Blake \& A.M. Martini. 1999. Coupling between 380 sulfur recycling and syndepositional carbonate dissolution: Evidence from oxygen and sulfur 381 isotope composition of pore water sulfate, south Florida platform, USA. Geochemica et 382 Cosmochimica Acta 63: 2529-2546. 
384 Light, S.S and Dineen, J.W. 1994. Water control in the Everglades: A historical perspective. In

385 S.M Davis and J.C. Ogden, eds. Everglades: The Ecosystem and its Restoration. St Lucie Press, 386 Delray Beach FL, pp 47-84.

387

388

389

390

391

392

393

394

395

396

397

398

399

400

401

402

403

404

405

406

McCormick, P.V., P.S. Rawlik, K. Lurding, E.P. Smith \& F.H. Sklar. 1996. Periphyton-water quality relationships along a nutrient gradient in the northern Florida Everglades. Journal of the North American Benthological Society 15: 433-449.

Noe, G.B., D.L. Childers, A.L. Edwards, E. Gaiser, K. Jayachandran, D. Lee, J. Meeder, J. Richards, L.J. Scinto, J.C. Trexler \& R.D. Jones. 2002. Short-term changes in an oligotrophic Everglades wetland ecosystem receiving experimental phosphorus enrichment. Biogeochemistry 59: $239-267$.

Noe, G.B., D.L. Childers \& R.D. Jones. 2001. Phosphorus biogeochemistry and the impact of phosphorus enrichment: Why is the everglades so unique? Ecosystems 4: 603-624.

Noe, G.B., L.J. Scinto, J. Taylor, D.L. Childers \& R.D. Jones, 2003. Phosphorus cycling and partitioning in oligotrophic and enriched Everglades wetland ecosystems: A radioisotope tracing study. Freshwater Biology 48: 1993-2008.

Perry, W. 2004. Elements of South Florida's Comprehensive Everglades Restoration Plan. Ecotoxicology 13: 185-193. 
407 Romero, L.M., T.J. Smith \& J.W. Fourqurean. 2005. Changes in mass and nutrient content of

408 wood during decomposition in a south Florida mangrove forest. Journal of Ecology 93: 618-631.

409

410 Ross, M.S., D.R. Reed, J.P. Sah, P.L. Ruiz \& M. Lewin. 2003. Vegetation:environment

411 relationships and water management in Shark Slough, Everglades National Park. Wetlands

412 Ecology and Management 11: 291-303.

413

414 Schwandes, L.P., M. Chen \& J. Galbraith. 2001. Total and extractable soil phosphorus in six

415 ecological communities of Florida. Soil and Crop Science Society of Florida Proceedings 60:

$416 \quad 53-56$.

417

418 Sherman, R.E., T.J. Fahey \& R.W. Howarth. 1998. Soil-plant interactions in a neotropical

419 mangrove forest: iron, phosphorus and sulfur dynamics. Oecologia 115: 553-563.

420

421 SPSS, Inc. 1999. SPSS Base 10.0 for Windows User's Guide. SPSS Inc., Chicago IL.

422

423 Stookey, L.L. 1970. Ferrozine-A new spectrophotometric reagent for iron. Analytical

424 Chemistry 42: 779-781.

425

426 Zhang, J.Z., C.J. Fisher \& P.B. Ortner. 2004. Potential availability of sedimentary phosphorus

427 to sediment resuspension in Florida Bay. Global Biogeochemical Cycles 18: GB4008.

428 
428 Table 1. Total phosphorus concentration in soils from the Shark River Slough (SRS) and Taylor 429 Slough/Panhandle (TS/Ph) transects in south Florida. For comparison, average concentrations 430 (standard error, $\mathrm{N}=9$ ) are expressed by soil weight and by soil volume.

431

432

\begin{tabular}{|c|c|c|c|c|c|}
\hline Sampling Site & $\begin{array}{c}\text { Total P } \\
\mu \mathrm{g} \mathrm{gdw}^{-1}\end{array}$ & $\begin{array}{l}\text { Total P } \\
\mu \mathrm{g} \mathrm{cm}^{-3}\end{array}$ & Sampling Site & $\begin{array}{c}\text { Total P } \\
\mu \mathrm{g} \mathrm{gdw}^{-1}\end{array}$ & $\begin{array}{l}\text { Total P } \\
\mu \mathrm{g} \mathrm{cm}^{-3}\end{array}$ \\
\hline SRS 1 & $\begin{array}{c}501 \\
(100)\end{array}$ & $\begin{array}{l}106 \\
(10)\end{array}$ & $\mathrm{TS} / \mathrm{Ph} 1$ & $\begin{array}{l}266 \\
(33)\end{array}$ & $\begin{array}{l}140 \\
(14)\end{array}$ \\
\hline SRS 2 & $\begin{array}{l}488 \\
(29)\end{array}$ & $\begin{array}{c}88 \\
(5.9)\end{array}$ & $\mathrm{TS} / \mathrm{Ph} 2$ & $\begin{array}{l}210 \\
(19)\end{array}$ & $\begin{array}{c}83 \\
(6.8)\end{array}$ \\
\hline SRS 3 & $\begin{array}{l}876 \\
(28)\end{array}$ & $\begin{array}{c}97 \\
(4.0)\end{array}$ & $\mathrm{TS} / \mathrm{Ph} 3$ & $\begin{array}{c}96 \\
(5.3)\end{array}$ & $\begin{array}{c}33 \\
(2.5)\end{array}$ \\
\hline SRS 4 & $\begin{array}{l}860 \\
(60)\end{array}$ & $\begin{array}{c}167 \\
(7.4)\end{array}$ & $\mathrm{TS} / \mathrm{Ph} 4$ & $\begin{array}{l}153 \\
(16)\end{array}$ & $\begin{array}{c}54 \\
(4.7)\end{array}$ \\
\hline SRS 5 & $\begin{array}{l}813 \\
(17)\end{array}$ & $\begin{array}{c}203 \\
(9.3)\end{array}$ & $\mathrm{TS} / \mathrm{Ph} 5$ & $\begin{array}{l}129 \\
(49)\end{array}$ & $\begin{array}{c}40 \\
(1.6)\end{array}$ \\
\hline \multirow[t]{6}{*}{ SRS 6} & $\begin{array}{l}533 \\
(77)\end{array}$ & $\begin{array}{c}297 \\
(6.5)\end{array}$ & $\mathrm{TS} / \mathrm{Ph} 6$ & $\begin{array}{c}59 \\
(3.7)\end{array}$ & $\begin{array}{c}45 \\
(2.2)\end{array}$ \\
\hline & & & $\mathrm{TS} / \mathrm{Ph} 7$ & $\begin{array}{l}362 \\
(32)\end{array}$ & $\begin{array}{c}171 \\
(5.3)\end{array}$ \\
\hline & & & $\mathrm{TS} / \mathrm{Ph} 8$ & $\begin{array}{l}454 \\
(24)\end{array}$ & $\begin{array}{l}160 \\
(11)\end{array}$ \\
\hline & & & $\mathrm{TS} / \mathrm{Ph} 9$ & $\begin{array}{l}228 \\
(35)\end{array}$ & $\begin{array}{l}141 \\
(21)\end{array}$ \\
\hline & & & $\mathrm{TS} / \mathrm{Ph} 10$ & $\begin{array}{c}71 \\
(9.6)\end{array}$ & $\begin{array}{c}60 \\
(2.2)\end{array}$ \\
\hline & & & $\mathrm{TS} / \mathrm{Ph} 11$ & $\begin{array}{l}296 \\
(31)\end{array}$ & $\begin{array}{l}199 \\
(13)\end{array}$ \\
\hline
\end{tabular}


434 Table 2. Summary of soil characteristics by drainage basin and habitat location along each transect. Values are grand means \pm

435 standard error. For each variable, letter superscripts show the results of post hoc comparisons among locations ( $\mathrm{p}<0.05$ ).

\begin{tabular}{|c|c|c|c|c|c|c|c|}
\hline Drainage Basin & Location & $\mathrm{N}$ & $\begin{array}{l}\text { Bulk Density } \\
\mathrm{g} \mathrm{cm}^{-3}\end{array}$ & $\%$ Organic & $\begin{array}{c}\mathrm{Fe}_{\mathrm{HCl}} \\
\mathrm{mg} \mathrm{gdw}^{-1}\end{array}$ & $\begin{array}{c}\text { AVS } \\
\text { mg gdw }^{-1}\end{array}$ & $\begin{array}{c}\text { CRS } \\
\text { mg gdw }^{-1}\end{array}$ \\
\hline \multirow[t]{3}{*}{ Shark River Slough } & Freshwater Marsh & 18 & $0.220 \pm 0.024^{\mathrm{a}}$ & $81.6 \pm 0.9^{\mathrm{d}}$ & $1.14 \pm 0.17^{\mathrm{a}}$ & $0.06 \pm 0.01^{\mathrm{a}}$ & $0.78 \pm 0.19^{b}$ \\
\hline & Marsh/Mangrove Ecotone & 18 & $0.156 \pm 0.013^{\mathrm{a}}$ & $83.7 \pm 0.9^{\mathrm{d}}$ & $1.22 \pm 0.21^{\mathrm{a}}$ & $0.07 \pm 0.01^{\mathrm{ab}}$ & $1.85 \pm 0.31^{\mathrm{c}}$ \\
\hline & Downstream Estuary & 18 & $0.450 \pm 0.080^{\mathrm{b}}$ & $47.1 \pm 13.5^{\mathrm{c}}$ & $0.83 \pm 0.10^{\mathrm{a}}$ & $0.05 \pm 0.01^{\mathrm{a}}$ & $2.85 \pm 0.49^{\mathrm{d}}$ \\
\hline \multirow{3}{*}{$\begin{array}{l}\text { Taylor } \\
\text { Slough/Panhandle }\end{array}$} & Freshwater Marsh & 27 & $0.443 \pm 0.025^{\mathrm{b}}$ & $14.4 \pm 1.7^{\mathrm{b}}$ & $3.16 \pm 0.37^{\mathrm{b}}$ & $0.04 \pm 0.01^{\mathrm{a}}$ & $0.24 \pm 0.04^{\mathrm{a}}$ \\
\hline & Marsh/Mangrove Ecotone & 45 & $0.491 \pm 0.030^{\mathrm{b}}$ & $35.8 \pm 7.1^{\mathrm{c}}$ & $1.67 \pm 0.15^{\mathrm{ab}}$ & $0.10 \pm 0.01^{\mathrm{b}}$ & $0.95 \pm 0.15^{\mathrm{b}}$ \\
\hline & Downstream Estuary & 15 & $0.677 \pm 0.082^{\mathrm{c}}$ & $6.6 \pm 0.3^{\mathrm{a}}$ & $1.04 \pm 0.48^{\mathrm{a}}$ & $0.06 \pm 0.03^{\mathrm{a}}$ & $0.49 \pm 0.06^{\mathrm{ab}}$ \\
\hline
\end{tabular}


437

438

439

440 the average percent of total $\mathrm{P}$ in parentheses. Operational definitions: $\mathrm{P}_{\mathrm{MgCl} 2}=$ loosely sorbed

441 inorganic $\mathrm{P} ; \mathrm{P}_{\mathrm{BD}}=$ inorganic $\mathrm{P}$ associated with metal oxides; $\mathrm{P}_{\mathrm{HCl}}=$ carbonate-bound inorganic

$442 \quad \mathrm{P} ; \mathrm{P}_{\text {Org }}=$ residual organic $\mathrm{P}$.

443

\begin{tabular}{|c|c|c|c|c|c|c|}
\hline $\begin{array}{l}\text { Drainage } \\
\text { Basin }\end{array}$ & Location & $\mathrm{N}$ & $\begin{array}{c}\mathrm{P}_{\mathrm{MgCl} 2} \\
\mu \mathrm{g} \mathrm{gdw}^{-1}\end{array}$ & $\begin{array}{c}\mathrm{P}_{\mathrm{BD}} \\
\mu \mathrm{g} \mathrm{gdw}^{-1}\end{array}$ & $\begin{array}{c}\mathrm{P}_{\mathrm{HCl}} \\
\mu \mathrm{g} \mathrm{gdw}^{-1}\end{array}$ & $\begin{array}{c}\mathrm{P}_{\mathrm{Org}} \\
\mu \mathrm{g} \mathrm{gdw}^{-1}\end{array}$ \\
\hline \multirow[t]{3}{*}{$\begin{array}{l}\text { Shark River } \\
\text { Slough }\end{array}$} & $\begin{array}{l}\text { Freshwater } \\
\text { Marsh }\end{array}$ & 18 & $\begin{array}{c}49 \pm 8.7 \\
(7.6)\end{array}$ & $\begin{array}{c}179 \pm 32 \\
(27.9)\end{array}$ & $\begin{array}{c}225 \pm 22 \\
(35.1)\end{array}$ & $\begin{array}{c}189 \pm 22 \\
(29.5)\end{array}$ \\
\hline & $\begin{array}{l}\text { Marsh/Mangrove } \\
\text { Ecotone }\end{array}$ & 18 & $\begin{array}{c}94 \pm 6.5 \\
(9.5)\end{array}$ & $\begin{array}{c}296 \pm 32 \\
(30.1)\end{array}$ & $\begin{array}{c}332 \pm 31 \\
(33.8)\end{array}$ & $\begin{array}{c}261 \pm 13 \\
(26.6)\end{array}$ \\
\hline & $\begin{array}{l}\text { Downstream } \\
\text { Estuary }\end{array}$ & 18 & $\begin{array}{l}41 \pm 6.5 \\
(6.8)\end{array}$ & $\begin{array}{c}104 \pm 14 \\
(17.1)\end{array}$ & $\begin{array}{c}267 \pm 20 \\
(43.9)\end{array}$ & $\begin{array}{c}196 \pm 21 \\
(32.2)\end{array}$ \\
\hline \multirow[t]{3}{*}{$\begin{array}{l}\text { Taylor Slough/ } \\
\text { Panhandle }\end{array}$} & $\begin{array}{l}\text { Freshwater } \\
\text { Marsh }\end{array}$ & 27 & $\begin{array}{c}32 \pm 4.3 \\
(10.0)\end{array}$ & $\begin{array}{c}83 \pm 13 \\
(26.1)\end{array}$ & $\begin{array}{c}126 \pm 16 \\
(39.2)\end{array}$ & $\begin{array}{c}79 \pm 9.0 \\
(24.7)\end{array}$ \\
\hline & $\begin{array}{l}\text { Marsh/Mangrove } \\
\text { Ecotone }\end{array}$ & 45 & $\begin{array}{l}20 \pm 3.4 \\
\quad(6.8)\end{array}$ & $\begin{array}{c}82 \pm 9.0 \\
(27.9)\end{array}$ & $\begin{array}{c}107 \pm 8.7 \\
(36.6)\end{array}$ & $\begin{array}{c}84 \pm 9.0 \\
(28.6)\end{array}$ \\
\hline & $\begin{array}{l}\text { Downstream } \\
\text { Estuary }\end{array}$ & 15 & $\begin{array}{c}21 \pm 8.7 \\
(6.9)\end{array}$ & $\begin{array}{c}87 \pm 35 \\
(29.5)\end{array}$ & $\begin{array}{c}104 \pm 23 \\
(35.2)\end{array}$ & $\begin{array}{c}84 \pm 32 \\
(28.4)\end{array}$ \\
\hline
\end{tabular}

Table 3. Summary of soil phosphorus fractions by drainage basin and habitat location along transect, expressed by soil weight. Values are grand mean concentrations \pm standard error, with 


\section{Figure Legends}

Figure 1. Map of south Florida, showing the location of the 17 LTER sampling sites arranged along Shark River Slough (SRS) and Taylor Slough/Panhandle (TS/Ph) transects. SRS 1, 2 and $\mathrm{TS} / \mathrm{Ph} \mathrm{1,} \mathrm{2,} 4$ are located in upstream freshwater marsh habitat, SRS 3, 4 and TS/Ph 3, 5, 6, 7, 8 are located in a mid-transect region including the marsh/mangrove ecotone, and SRS 5, 6 and $\mathrm{TS} / \mathrm{Ph} 9,10,11$ are located in the downstream estuary.

Figure 2. Average concentration and standard error of a) total phosphorus and b) total inorganic sulfide in soils from the upstream freshwater marsh, the mid-transect region including the marsh/mangrove ecotone and the downstream estuary along SRS and TS/Ph transects. 

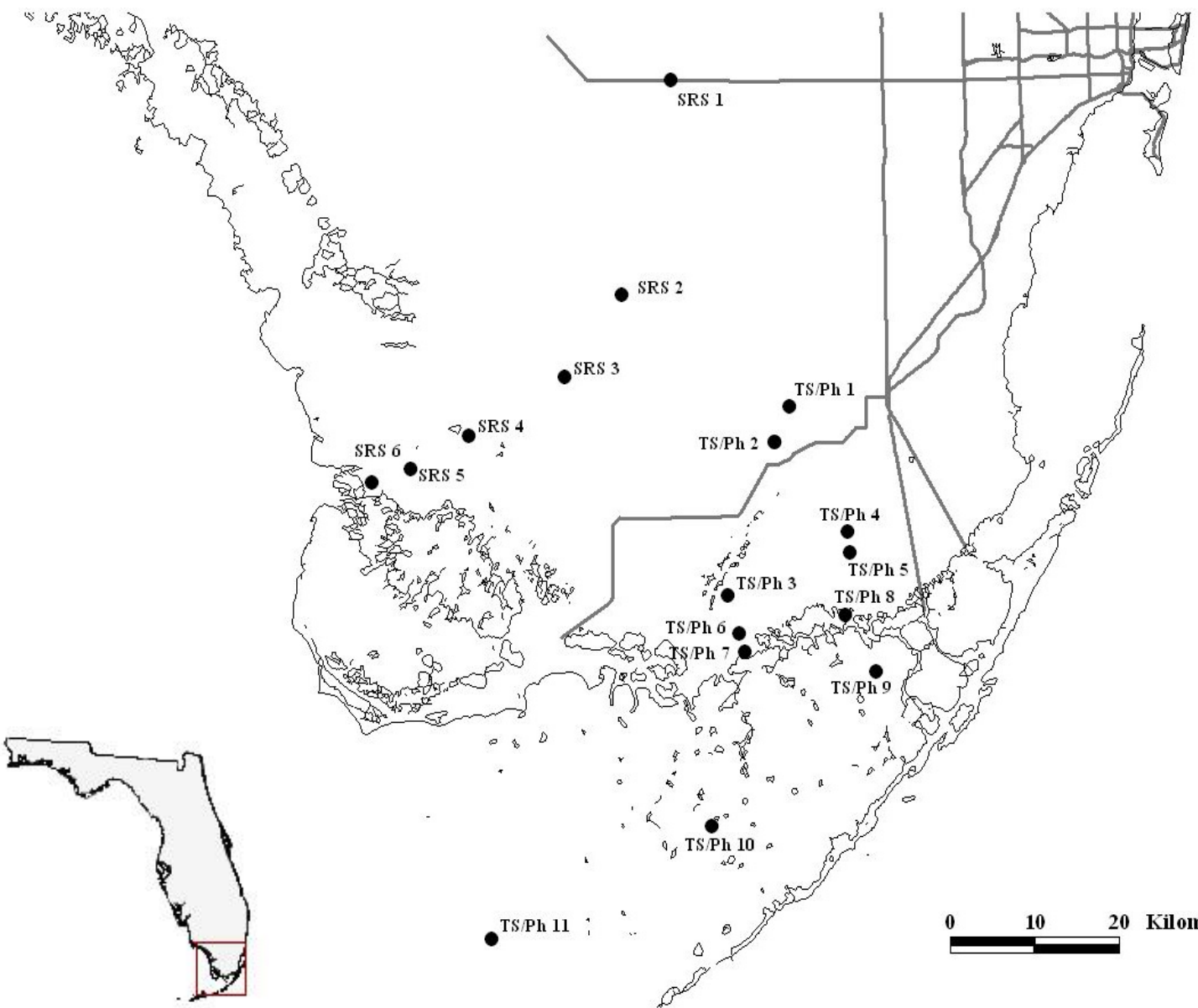

-SRS 3
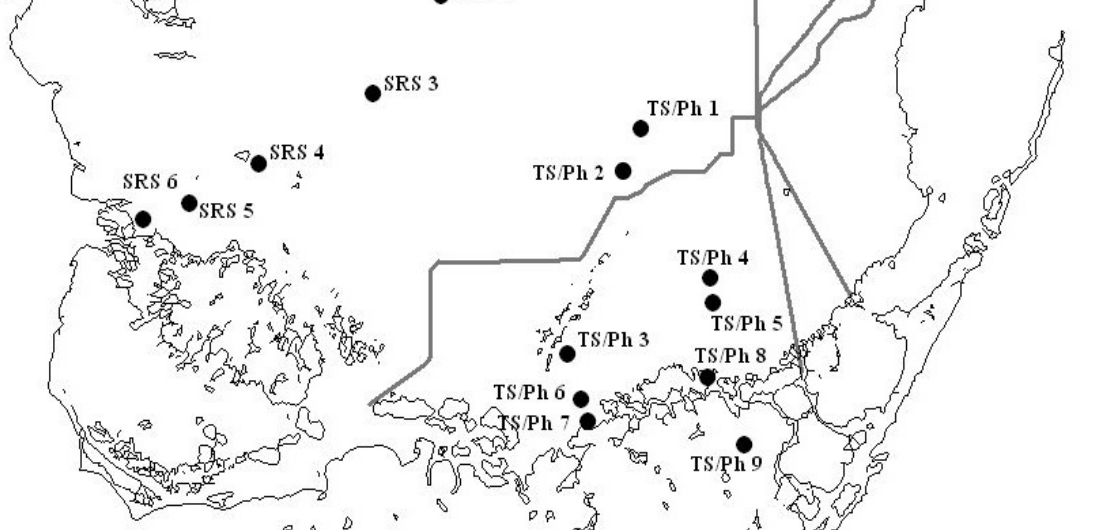

472

473 

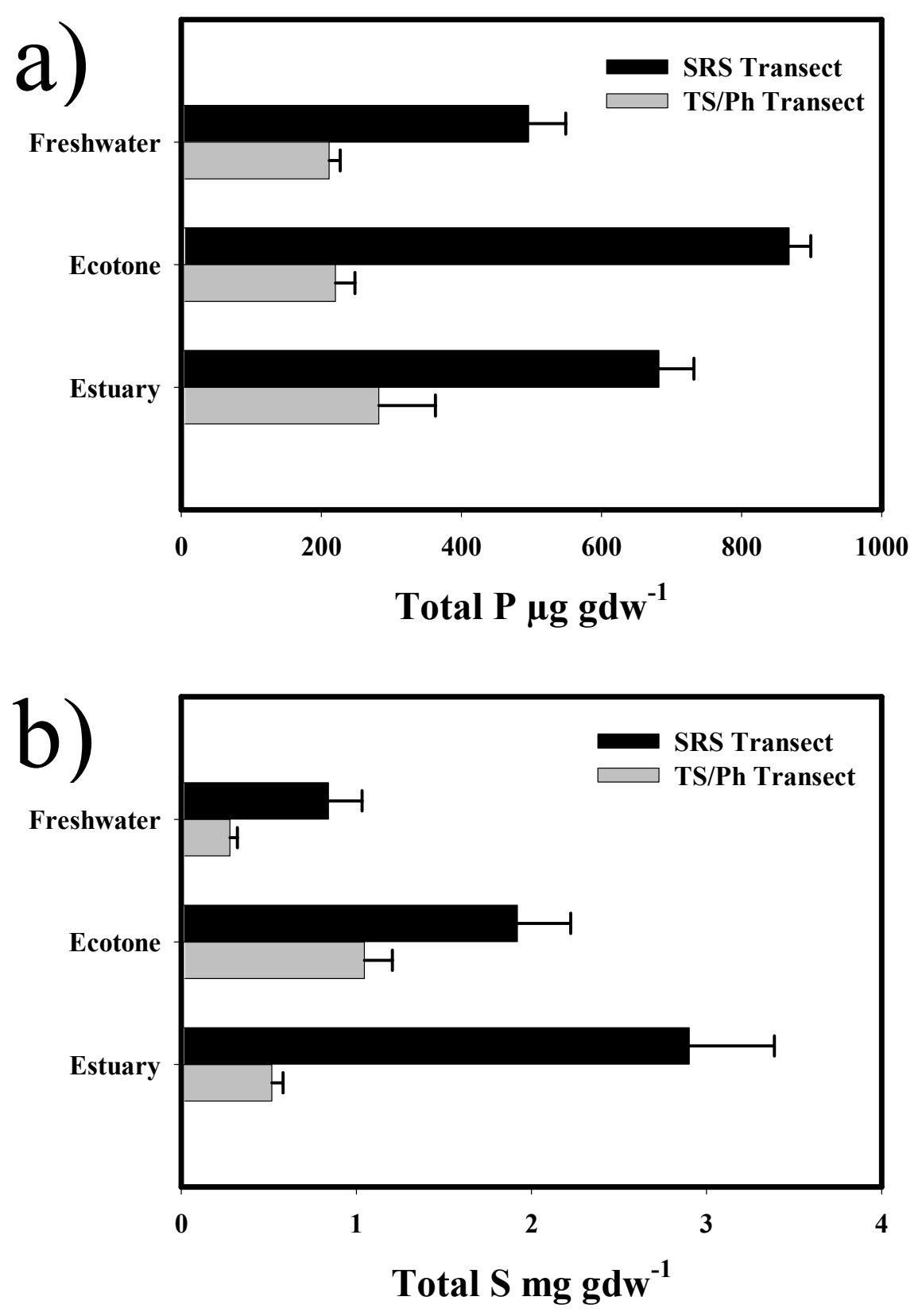